\title{
Comparative Study of Cultural Value Orientation between China and America
}

\author{
Jie Yan \\ Foreign Languages College, Jiangxi Normal University, Nanchang, China \\ Yuying Li \\ Foreign Languages College, Jiangxi Normal University, Nanchang, 330022, China
}

\begin{abstract}
In today's world, cultural exchanges have become more and more frequent because of the economic integration and technological globalization, but people from different countries may have different culture values. China and the United States, as representatives of the East and the West, also have great differences in value orientation. Therefore, understanding the differences between each culture has both theoretical and practical significance for their inter-cultural communication. This paper analyzes the differences between Chinese and American cultural values from five aspects: nature, humanity, time, relationship, and human actions. It will have an important guiding role in eliminating cultural barriers and promoting the development of Chinese and American culture in inter-cultural communication.
\end{abstract}

Index Terms - cultural differences, cultural values, social relationship, inter-cultural communication, mode of thinking

\section{INTRODUCTION}

Culture is characterized by diversity and permeability, and it is these characteristics that make it complicated. Cultural values not only represent the core concept of a nation, but also a bridge for communication among different countries. They are closely related, because different values are all embodied in their culture. Intercultural communication also plays an important role in real life. People from different countries have different values, which makes it difficult for them to communicate with each other. Therefore, understanding the different values between Chinese and Americans can greatly help them to strengthen the exchanges and cooperation. Nowadays, with the development of economy and society, the exchanges between China and the West have become more and more frequent, and the cultures from different countries have influenced each other. A contrastive study of differences in cultural values orientation between Chinese and American can help people clearly understand the differences in the cultural spirit, modes of thinking, and values among various nationalities. Thus, Chinese and the Americans can better know each other and communicate efficiently.

\section{THE THEORETICAL FOUNDATION}

Florence Kluckhohn and Fred Strodtbeck were the two American anthropologists who proposed cultural theories earlier than any others. During the Pacific War, Florence Kluckhohn, a woman scholar, coming from the Harvard University, was part of a team of about 30 experts assembled by the Office of War Information, and dedicated to study the values, popular sentiments and morale from different cultures. Based on an analysis of the psychology and values of the Japanese, the team proposed to the U.S. government that it should not strike or abolish the opinion of the emperor of Japan, on the contrary, the declaration calling for Japan's unconditional surrender should be revised. Shortly after World War II, Harvard University accelerated its support for the study of cultural value dimensions, and, together with the Rockefeller foundation, launched a massive research campaign for value concept coming from five different cultural communities in a 40-mile area of Texas. A major achievement of this work was the five patterns of Value Orientations published in Variations in Value Orientations by Kluckhohn \& Strodtbeck. Value orientation refers to that "It is a complex but exact and patterned principle, associated with coping with the problems of the ordinary people, which can instruct and guide the behavior and thought of human beings" (Kluckhohn \& Strodtbeck, 1961, p.4).This model includes five value orientations: human nature orientation, relationship orientation between human and nature, time orientation, activity orientation and relationship orientation.

Kluckhohn and Stodbeck's mode of value orientation is based on three basic assumptions:

(1) People no matter what era they live must provide a solution to the common problems for certain human beings;

(2) The solution to these problems is not infinite or arbitrary, but can be changeable in a series of choices or values.

(3) Each value orientation exists in all societies and individuals, but each of them has different preferences for value orientation. 
Human orientation involves the intrinsic characteristics of human nature. Kluckhohn \& Strodtbeck (1961, p.4) argued that when answering questions about human sexual orientation, there are two aspects to be considered. The first is that whether human nature is good, evil or a mixture of both; secondly, whether it can be variable or not. In addition, they further suggested that "mixed" humanity can mean either good and evil or no good and evil.

People from different cultures may have very different views on human nature. Influenced by Christianity, westerners usually advocate the original sin theory and believe that human nature is evil, while, the Chinese believe that human nature is good, because they are deeply influenced by Confucianism. It is complicated for Americans to hold a view toward human nature. They do not simply think that one was born to be good or sinister, but that human nature can be mixed: either good or evil. They also believe that the good and evil of human nature may change after their birth. It advocates that people can be atoned and get rid of all the bitterness and finally ascend to heaven through confession and doing good deeds, which strongly illustrates the idea that human nature can be variable.

\section{B. Relationship Orientation between Human and Nature}

According to the pattern of value orientation of Kluckhohn \& Strodtbeck, there are three potential relationships between man and nature. They are whether we should conquer the nature, live in harmony with it or have no choice but obey it.

The Confucian view of human nature interpreted the relationship between man and nature from the perspective of the integration of man and nature. He believed that man and nature should be in a harmonious state, showing the idea of unity between man and nature. Mencius who believed that human can know the world through heart and mind associated heaven with human mind and pointed out that people should obey and follow the willing of heavens, and should always be sincere and innocent. Human beings should preserve, expand and carry forward the gifts that given by God in order to achieve the goal of unity between mankind and heaven.

However, western humanism advocated that people should use their rationality and determination to change the atmosphere around them, People should be encouraged to conquer nature and enjoy the life of the real world. The core view of this orientation held that all natural forces could be conquered and utilized.

In addition to the above two orientations, some cultures believed that human should be obedient to nature. Most Southeast Asians insisted on this point. They argued that the advent of the natural disaster was the result of human's offense of the nature.

\section{Time Orientation}

The human's time orientation can be divided into three types: first, it is past-orientation, which emphasizes tradition and respecting history. Second, it is present-oriented, usually focusing on short-term and current things. Third, it is future-oriented, which attaches more importance to long-term and changeable things.

The past-orientation mainly attaches great importance to tradition. The Chinese are typical of sticking to the past. They worship their ancestors, respect the elderly and teachers, and age and experience should be valued in the work. In Chinese society, people are less interested in the future unless it is an ideal one. When people do things that have never been done before, they often inclined to consider whether this matter has been done in the past, any successful experience can be used for reference, or what lessons should be learned from failure. So following the rules has become a social norm.

While, present-oriented people are less concerned about what has happened in the past and what might happen in the future. People think that the most important thing is only at the present. They tend to focus only on what is happening right now and hardly plan for tomorrow. Traditional Islamic culture belongs to this type of culture. They believe that the future is belonging to God and is not controlled by mortals. The culture of the Philippines, some countries in Latin America, and the northern Indians of Arizona in the United States can also be classified into this type. These cultures have more arbitrariness and randomness in their attitude towards time than any other cultures. This style of indifference to time often makes westerners misunderstood and treats them as being lazy and inefficient.

When it comes to the future-orientated people, they always put more emphasis on changes. In their society, change is often considered necessary and beneficial, while the past is outdated and should be abandoned. Both Kluckhohn \& Strodtbeck (1961) and Hall (1996) believed that this time orientation exists in American society. In the United States, the variety of new products and various fashionable packages are being constantly updated every day, because they believe that this is the only way to attract customers. On the contrary, in the past Chinese society, people usually believe in old brands.

\section{Activity Orientation}

There are three types of human activities-orientation, which are doing, being, and being-in-becoming (Kluckhohn \& Strodtbeck, 1961, p.6). American lives in a society that emphasizes action ("doing"). They maintain that people must constantly do things, and only when they are constantly working, can they create value and live meaningful. In order to get promoted, Americans work hard for their prominent achievements. When evaluating a person, the Americans always ask "What did he/she do?" and "What achievement did he/she have?" If a person just sits there thinking, which means that he is just doing nothing, because thinking neither can be quantified, nor be measured. 
The "being" orientation is just the opposite of the "doing" one. Tranquility and patience can be seen as one of the virtues, instead of the doing for nothing. Chinese culture belongs to this orientation, advocating "the static against the dynamic" and "cope with all shifting events by sticking to the fundamental principle." In addition, in China, when people want to know a person, they always first inquire about his background, such as the origin of his family, education degree, job occupation, social relationship, etc., instead of his achievement.

The "being-in-becoming" orientation emphasizes "who we are" rather than what we did (Kluckhohn \& Strodtbeck, 1961,p.6). The ultimate goal of what they strive for is to become more perfect themselves in the process of self-development. A typical example of this orientation is a monk of Chan Sect, who will spend all his lifetime in meditation and contemplation in order to make himself complete.

\section{E. Relationship Orientation}

As for how to deal with the relationship among people, Kluckhohn \& Strodtbeck (1961, p.6) once proposed that humans also tend to have three orientations, which are individualistic, hierarchical and subsidiary orientation. Individualistic orientation is characterized by personal autonomy, and each individual is considered to be a unique independent one. Under this circumstance, an individual's goals and objectives is superior to those of the group's.

The hierarchical orientation focuses on the group, undoubtedly, the group's goal is better than that of the individual's (Kluckhohn \& Strodtbeck, 1961, p.9). People living in a hierarchical society tend to be ruled by aristocracy. A typical example of this orientation exists in many European countries. While, people from individualistic orientated culture emphasize more about independence and freedom. Therefore, it is normal that American young people would rather live away from home when they are 18 years old, even if their school or work place is close to their family. They prefer to find another house living independently.

If you properly use the five value orientation theories proposed by Kluckhohn \& Strodtbeck to distinguish culture in our real life, you can better understand many certain of the cultural differences and can explain such "abnormal" behaviors reasonably. From his own research, Kluckhohn \& Strodtbeck concluded that people from different nationalities and countries may inevitably have quite different ideas on these five issues, which can significantly affects their attitudes and behaviors in their life and work. But the theory does not explore the deeper reasons why different countries and nations are so distinguish in these five values orientation. I must reaffirm that this theory is not a universal formula, therefore, while analyzing different cultural values, we must learn to analyze cultural phenomena from a dialectical perspective.

\section{DifFerences of Cultural Values Between China AND AmericA}

\section{A. Chinese Attach Importance to Be Implicit}

The way of Chinese thinking has been from the Confucius who advocated the Mean for a thousand years, which has been rooted deeply in Chinese traditional culture. Its core connotation is to warn people to maintain the principle of neutrality when dealing with everything. Under the influence of this kind of thinking, people are used to treating others with courtesy and humility. Praised, they always behave modestly, and they are also ashamed of being criticized. There are three aspects in the moral principles of traditional Chinese culture. First, people should correctly evaluate themselves and have an overall understanding about them, understand your own shortcomings and the strengths of others, and be willing to learn from others, stay humble, and never overstate and boast of what you have achieved. Second, people should respect others, be tolerant of accepting others' defects, and learn how to be temperate and polite. Third, when people show their advantages and achievements to others, they should not be more exciting. Therefore, once praised from others, the Chinese always appear shy and modest.

\section{B. Americans Attach Importance to Be Direct}

Americans never say a word for roundabout in their conversation. If they don't agree with you, they will speak the opinions from their hearts and directly refute them. In the past, the early settlers fought for the right for freedom to break the steady status of the aristocracy and get more space. In the early Puritans' thoughts, it was especially important to express the ideas in a straightforward way, which meant that everyone is equal. The social development depends on how to express your will and communicate with others efficiently. What you should do is that you must totally convey the idea you want to express into the others' ears, which has none business with your character or the way of your expression. Americans believe that everyone has a reasonable and legitimate individual right from his birth, which is a guarantee that everyone can obtain what you should get as an individual in a free society.

\section{Chinese Attach Importance to Be Ethical}

Many anthropologists and sociologists believe that geography factors have a significant impact on culture in a primitive society or a country with underdeveloped economy. The geographical feature of the isolation from the mountains makes China become an agricultural country. Chinese culture originated from the Yellow River. The advantages of water source have brought positive impacts on crops, which greatly promoted the agricultural development, and also shaped the social form that has existed for a long time in China. Two-thirds of the population still depends on the land for survival. There was such large number of the population that the agricultural value is 
superior to industry and commerce. At the same time, Chinese people attached more importance on moral and ethics, owing to its social values and unique way of thinking. Ethics mainly emphasizes how to cultivate and establish the human morality. People always paid attention to how to become a noble man and how to cultivate people's attitudes during that period. Confucius once said that the one who is of benevolent will master the world. The benevolence and righteousness meant just like the two proverbs that love me, love my dog and don't do to others what you don't want others to do to you. The ancient Chinese believed in that their desire should be self-restraint, the thought of greed or getting without paying should be abandoned.

\section{Americans Attach Importance to Be Pragmatic}

Americans believe that rich material and comfortable spirit are necessary conditions for people's lives. For example, they always enjoy the fast and convenient transportation, all kinds of natural and healthy food, and the full use of household appliances, including air conditioning and bathtubs, etc. They can get adequate food and medicine from the federal government, and the basic welfare from a large number of private institutions. To have a healthy body and live longer, they like spending a lot of time on exercise or fitness in the gym. At the same time, they also pay more attention to keep the air clean and improve the sanitary conditions. People strive to use new technology to improve their own living conditions, which can constantly create new scientific and technological inventions and promote the advancement of new technology. Americans regard it as a universal living standard. They also want to have a longer life expectancy and lower rate of death from illnesses and accidents and think that people from different countries should lead such a mode of life in many fields, such as, in basic material supply, necessary physical facilities and extensive health care service. Americans often hold a point of view that science and technology should serve for people, so most of them tend to think that they can find solutions to deal with all kinds of the problems relying on commerce, science and technology. To lead a better life, Americans manage to create some new industrial products to make their daily life more convenient and efficient. They always believe that with the development of science and technology tomorrow will be better. Everyone wants to make great progresses, but it is a ridiculous view that individuals may not need to care about others, in order to obtain more. If they strongly insist on this point, it means that personal selfishness will deprive of others' rights to some extent. The aim of foundation of the US Constitution and the basic tenet of American democracy is to protect private property from infringement. Many Americans can clearly distinguish the private and public property in dealing with interpersonal relationships. A case in point is that how to separate the common property democratically between a couple after the divorce. Continuous improvement and constant challenge are the characteristics of Americans, which also best embody the value of American individualism.

\section{DIFFERENCES FROM THE ORIENTATION OF CULTURAL VALUES}

\section{A. Different Attitudes towards the Nature}

People treat the natural environment in different ways due to the cultural differences, which can roughly be divided into two kinds: people should live in harmony with nature, and humans can dominate nature. The former represents Chinese traditional values, while the latter is the core concept of Western values that affect the United States.

1. Chinese Harmonious Orientation

The Chinese culture had always pursued the traditional philosophy of human and nature is integrated. It was a fact to Chinese that nature had a superpower, which was difficult for human to be overcome. For nature, human beings lie in a subordinate position. Therefore, people should follow the laws of nature instead of violating them. The ancient Chinese always believed that there had a tightly relationship between man and nature, which were interdependent. In order to accumulate experience and apply it to future production and life, they were constantly concerned about the subtle changes of nature, and try to find more information about them. The thought initiated from Confucius who put forward the concept of Sensation between Heaven and Human at the end of the Spring and Autumn Period and Dong Zhongshu, a famous scholar in Han Dynasty, once proposed a theory of the unity of heaven and man to further interpret the relationship between man and nature. To survive, people must follow the laws of nature which were based on the changes with the rise and fall of the sun and moon and the regular cycle of annual climate. They could remind people how to adjust their schedule and when they should sow and harvest. In China, Confucianism advocated that people and nature should live in harmony and unity, which had deeply affected the mode of thinking of Chinese people. The old saying Man proposes, God disposes showed that people and nature are inseparable. It was Chinese traditional belief that if you wanted to get more from nature, we must treat it in a harmonious way, neither doing nothing nor overdoing.

\section{Americans' Mastery Orientation}

The United States whose history is very short is one of the countries that deeply affected by typical western values under the capitalist system. The Americans always hold the point that human have the ability to conquer the nature. In the attitude toward nature, the spirit of conquest is the typical characteristic of American people. They believe that human and nature are mutually independent. So if you want to get what you want to live better, you must make new inventions to improve our living condition and fight for all kinds of natural disasters, such as flood, earthquake, hurricane, etc. As a natural conqueror, they also insist on that the potential of human should be infinite without any restrictions, which can make them try their best to change everything. The power comes from the westerners who regard God as faith. In the biblical record, God created everything in the world by kneading soil with the fingers and 
told Adam to use all his human power to meet the demand from nature, which was recorded in Bible. Man, as the master of nature, was encouraged by God to improve nature to meet human's living conditions. Therefore, Americans regarded people as a prerequisite which was capable of defeating nature and really had the superpower to dominate it. To lead a better life, they must constantly keep improving the natural environment. The disasters which Americans fought for in the past not only destroyed a large number of houses, but also brought various diseases which could threaten people's health. Although these disasters had caused irreparable damage to the local residents to some extent, they used to take a positive response, such as giving a speech to encourage people to rebuild their confidence, and try to use advanced technology to improve the ability to prevent them. After experiencing the natural disasters, the Americans confidence had never been directly defeated. On the contrary, the disasters would make them stronger and stronger. Americans believed that through the deep understanding of nature, human could overcome disasters, diseases and other difficulties to survive and make more progresses. Americans' positive behavior shaped their unique character, which enabled them to cope with more new challenges from nature.

To sum up, different people have different attitude toward the nature, which can affect the way in their inter-cultural communication.

\section{B. Different Attitudes towards the Humanity}

From ancient times to the present, different people have different ideas about whether people were born to be kind or evil. There are three kinds of hypotheses: human nature is good, evil or mixed. Knowing different cultures, we can better understand why people respond differently to the same thing.

1. Chinese Kind Orientation

In Chinese traditional culture, people believed that human were born to be kind, which was also an important thought of Chinese traditional philosophy. Among them, Confucius was a typical representative of this idea. He proposed Benevolence means to love others, that is, the human's righteousness and generosity enabled them to love other people. Another traditional philosopher, Mencius, further promoted this theory, he believed people have the sense of compassion, shame and right and wrong. So they could sympathize with others who were unfortunate, be ashamed of his wrong behavior, and change the defects in his humanity. They were conscious of that one should do more kind and fight for something bad, so they must have the ability to judge people from their behavior. As a whole, the Chinese believe that Man's nature at birth is good in the traditional culture. The ancient Chinese believed that the human nature was not pure essentially, so most people would have the infinite desire. Only by constant self-cultivation can they reach the highest realm of the rational spirit. This theory emphasized the kindness of human nature was really important and more emotional desires would eventually lead to evil, which had a deep impact on Chinese moral concept. Traditional Confucianism told young children that they came to the world with a pure and kind heart from the very beginning, but when they grew up, they became morally corrupt and degenerate. At the same time, children had always been cultivated into those who should have a modest attitude to anyone when they began to their family education, so they were highly hoped by their parents to try to become what their parents had expected, which was also the ultimate goal of traditional Chinese education.

\section{Americans' Mixed Orientation}

The Puritans of the United States considered the humanity as both good and bad, which inherited from the westerners. They always firmly believed that if you followed the steps of God, you would save the evil side of humanity. They also believed that as long as they followed the rules and regulations of the Bible, including making efforts to survive, controlling their own desires, and achieving perfect self-restraint, they would eventually be able to be free from the suffering and gain their own happiness. So human nature was a mixture of kindness and evil in Americans' eyes, which always changed with the environment. Americans clarified all kinds of human evils according to the famous Seven Deadly Sins in the United States. If people did something good in bad situations and got redemption through confession, they would finally go into heaven, which represented the characteristics of the variable human nature. Nowadays, however, they were more willing to believe that people could escape from evil humanity, not only just by believing in God, but also by virtue of the good education and environment. The typical example embodies in the US political system. The American Judicial, legislative and executive departments and media reporters always paid more attention to the president's words and deeds, ensuring that nothing evil things would be done by him. As soon as there was something mistake he had made, he would be punished and dismissed immediately. The different way of the criticism of human nature in government's power mechanism between the United States and China showed that the federal government is unable to take power, whose rights were always supervised by other agencies, such as the image of the president and the state officials, to ensure that they never abused power and never violate the rights of the people. If they really did such things, they would be severely punished and even stepped down from the post. The attitude towards humanity in modern western values is not only influenced by religion, but also had a profound influence on Freud's psychological theory. He also believes that a baby was branded with sin when he was born, only by the continuous efforts can he become a healthy person. Based on the above argument, we know that it is the shame culture that constitutes the Chinese core value, while western value attaches importance to the sin culture. The former explained what they expected is always contrary to what they did in their life practice. And the latter is the representative of the sin culture, which means that human nature can be either good or evil, so it should be improved in their future life. This idea is not only spread by today's Americans through religion, but also publicized by means of educational and other 
positive self-motivation methods, such as speeches, TV shows, and books, to share the ways how to successfully change them, which means good things tend to be positively improved and will become better and bad things always inclined to be negatively declined and will become even more worse. This distinction between good and bad can be found everywhere in society: superman can not only save the world, but also can defeat the evil forces; successful employees can be promoted quickly in the office, while frustrated employees in their career are immediately dismissed; celebrities who are aggressive will be sought after, and superstars who are infamous will disappear from people's sight. Based on the above analysis, we can draw the conclusion that in the Americans' eyes, human nature can be improved to a higher level where the sin from human can be purified.

\section{Different Attitudes towards the Time}

The attitudes to time in different cultures are also not the same.

1. Chinese Past Orientation

Traditional Chinese culture regarded historical heritage and cultural customs as a valuable asset, which was an important component in Chinese traditional culture. They believed that they could reveal what had happened in the past relying on historical clues, such as archeology. At the same time, they were also proud of having a long history and colorful culture which handed down from their ancestors who were always considered to have the invisible power to bring the good to the next generations and direct the way for their future life. The memory of history could be recorded in traditional culture from every aspect. It may be from a sentence, an article or a book, which could help you to understand everything in the world. Traditional Chinese believed that they could learn the experience from what had happened in the past. The pursuit of traditional history of thousands of years has kept people's minds from changing. Therefore, the Chinese people had a habit of drawing portray for the history, which was fully reflected in books, TV documentaries, music or story introductions. The Chinese are used to reminding of the various famous figures from different dynasties in ancient times. In addition, they also mourned their late relatives and family ancestors to affirm their historical achievements and showed the respect for them. The traditional Chinese always respected for what happened in the past before taking new actions or making new decisions. They believed that longer time they spent, easier for them to cope with when they were in trouble. For example, in a business negotiation, a topic would always be discussed for a long time. Chinese people are also inclined to respect the elderly, whose words should be followed by the younger generation as a symbol of wisdom.

2. Americans' Future Orientation

The Americans whose style of working is not limited to the original mode, they don't like following the old rules to do something. However, they are often determined to make great progresses and commit themselves to continuous innovation. People will never be willing to keep the present condition and follow the traditional social orders, they believe everything can be changed in every aspect, so they often try their best to improve themselves and achieve greater success. The idea is not only in their lives, but also in people's work, study, and family. For example, innovation has been ingrained in American concept. The products of Apple mobile phone have been updated for many times. However, in China, people are more inclined to trust old brands. When comparing with the past, Americans concern more about the future.

\section{Different Attitudes towards the Relationship}

The human attitude to relationship can roughly be divided into two types: collective or individualism orientation.

1. Chinese Collective Orientation

The way of Chinese behavior has a deep impact on Confucius who believed that in order to keep things stable, people should coexist harmoniously with everything around them. Most of the time, the Chinese are not used to showing their true feelings until they have observed what other people around them did and what they said. And they also consider that whether their own words and deeds are always consistent with others, so that they can better get along with others. In order to close contact with other members and live in the harmonious atmosphere, people should sacrifice themselves. Therefore, Chinese people like working together with their intimate friends to achieve their goals. When your own ideas conflict with collective decisions, you should give up your own benefit and keep in line with the collective opinion. The proverb Worrying before the Common People Worry; Enjoy only after the People can Enjoy better embodies this collectivist value.

2. Americans' Individual Orientation

Americans specially place an emphasis on individualism and believe that the existence value of a man is paramount. Because Americans can effectively be self-restrained, they can avoid being subjectively interfered by others, which may hinder the free development of individuals. If you count how many times the Americans use the prefix self in their daily life, you will know the importance of the concept of individualism. In fact, every American wants to be an entrepreneur who starts from scratch. Western philosophers believed that contradictions were ubiquitous in the world. From the formation of the universe, human beings have been trying their best to conquer the nature. If they can't get what they want or realize their ambitions, they won't admit that it is their own destiny and they are doomed to be a loser. The individualistic idea came from the Westward Movement, which left behind the invaluable cultural heritage to them. During the colonial period, the early American immigrants got rid of the rule from Europeans, which ended the feudal shackles of the colonists, but at the same time they lost the comfortable life of European civilized society. In order to 
survive, they had to compete with the ancient Indians on this virgin continent and made them accustomed to using guns and axes to drive away the foreign invaders. This spirit made people look forward to building an ecological environment in which could be suitable for humans to settle down in the wilderness. Therefore, they have the characteristics of pursuing personal happiness, striving for individual rights, daring to challenge authority, encouraging free development, which can finally achieve the great success.

\section{E. Different Attitudes towards the Human Actions}

\section{Chinese "Being" Orientation}

Maintaining the tradition means pursuing a steady state of mind and a comfortable life. The aim of self-cultivation is to improve the moral standard through deep understanding of virtue and profound insights into arts. Only if the spiritual world of a man is rich enough can he live in harmony with the outside world, which more emphasizes the improvement of people's morality and spiritual realm, rather than paying too much attention to material wealth. Influenced on Hinduism and Buddhism, the congregation spent most of their time pondering their thoughts, feeling the true meaning of life, trying to purify themselves and finally wanted to achieve an overall improvement in their self-cultivation. Chinese traditional culture pays more attention to the thought of seeking stability, which reflected in many aspects. For example, no matter in the ancient or modern society, traditional Chinese women are taught to be quiet and elegant, It is their special character that they had made the exquisite embroidery crafts which are well-known to the world. The ancient Chinese people often called the place where they lived in hometown, and hoped to live there from their birth to death. Even when they faced such a huge disaster, such as war and famine, they were reluctant to leave it. Although they had to move to another place, they would let out the sigh in a famous poem: Alone, a lonely stranger in a foreign land, I miss my dear ones far away on festival occasions more than ever. There are three main reasons for this concept: First, Chinese civilization is based on agriculture, and the dependence on lands makes people from generations to generations have the special feelings for them, so it is hard to make people leave their original residence whether it is social factors or geographical environmental factors. Second, due to the special geographical location, the mountains and rivers on the borders of China isolated themselves from other neighboring countries, so it is difficult to better communicate with each other. Third, people helped and supported each other to lead stable and ease life, they could hardly change the idea that human and nature are harmonious. Still retaining the inherent ideology caused by the long-standing feudal system, most people unwilling to face change and migration. Li Dazhao once pointed out that the Eastern civilization belongs to a quiet one, which is quite in line with China's national character. Taoism advocates acting following natural law, which means that one should maintain the current state, so as to prevent confrontation from doing something. Similarly, people pay more attention to how you behaved than how many things you did. When talking about a person, people care about their background, such as their family, education, occupation, social status and so on, whether they are good fathers, mothers and teachers or not, which is quite different from the United States' opinions about personal achievement. So the concept of Chinese value is to keep stability.

\section{Americans" "Doing" Orientation}

The United States of America was founded less than 300 years. Some people say that it is a country with no history. They do not mean that the history of the United States is very short, but that Americans always look forward to the future and do not like dwelling on the past. Just as the old saying goes where there is a will, there is a way, Americans believe that everything is changeable all the time and never stops. They also believe that only by constantly exploring the universe, can human beings better control the nature. So they are dedicated to the development of science and technology to make full use of them. They strive to improve the living conditions of human beings, which make them have great confident in the future. In short, for Americans, change, development, progress and possibility will bring a bright future to mankind. In American's eyes, judging whether a person is successful or not depends on what he has achieved. Just as another old saying goes Actions speak louder than words. In the American family, when there is something wrong with their tools, they will repair them by themselves, which is a common practice for them. There are some surnames in the United States, such as Baker, Blacksmith, Carpenter, etc., which comes from the name of a profession, which shows their attention to action. The style of doing things in Chinese culture is not appreciated by the Americans, who think that it is an immoral behavior to force oneself to cater to others, which is considered a negative behavior by them. People will be promoted and raised through hard work to meet their own desires and requirements.

\section{REASONS FOR THE DIFFERENCES OF CULTURAL VALUES}

\section{A. Differences from History Background}

Chinese culture has a history of 5,000 years. This long-established civilized society was based on the long-term feudal system, which had a highly concentrated rule and a single social consciousness. Influenced by the feudal system of the family conception, the goals of the people from the same family were highly unified, although they had different social status and occupations. On the basis of such ideology, people lived together with the elders and younger generations, so each person's identity and responsibility were subject to the social constraints. For the sake of harmony and stability, all members of the big family could even give up their personal wishes and work hard together to achieve the same goal. Under this condition, despite the close relationship between them was enhanced, the particularity of the individual had not been taken seriously. The core of social thought was collectivism, which meant the individual's will 
could not violate the overall values of society. In Chinese traditional society, the basic principle of the Confucianism ethics morals was the Three Cardinal Guides: ruler guides subject, father guides son and husband guides wife, which embodied the strict hierarchy of feudal society, so different hierarchy would inevitably have different social status. In short, it is the collectivism, hierarchy, and social integration that constitute China's social ethical standards.

American history is very short compared to that of Chinese, but Americans always has a strong desire for pursuing individual freedom and rights. In order to get rid of the feudal rule of Europe, the early immigrants crossed the sea and reached the American continent to settle down, and finally defeated the British colonists and established the United States of America in 1776. Americans would fight against the forces that would limit their personal rights and freedoms, whether they are governments, churches, or other rights controllers. They were eager to have the power to decide their own destiny. So they eventually forced the King of England to give up jurisdiction over the Americans and admitted the independence of the United States. Americans don't like to rely on family or government, but want to change themselves and create everything possible through self-effort. The United States is also an immigrant country with a long history. When arriving at the New World, the immigrants from all over the world must overcome great difficulties and learn to survive in adversity in order to build a better life. Self-reliance, independence, and diligence are the invaluable qualities which they have passed down from generation to generation. For them, the old experience is less useful, so they must rely on themselves and face reality and learn to be independent. Instead of inheriting the legacy and rights from their ancestors, they usually make full use of opportunities to achieve new success, which formed Americans with broad mind and innovative spirit.

\section{B. Differences from Religious Belief and Mode of Thoughts}

The core concept of Chinese traditional philosophy is Human and Nature are Integrated, which emphasizes more about spirit and ethics. People believe that the destiny of a man is determined by heaven. However, the lack of logical theory of thinking, there is no subject and object in the natural sciences, which is quite different from the philosophical thinking under the western values of the United States. It comes from Confucius who paid more attention to Benevolence and Ritualism. In order to live in a harmonious society, people should be polite and respect each other. The thoughts of Taoism and Buddhism also have a huge impact on the Chinese. The outstanding representative of Taoism is Laozi who advocated that people should follow the rules of nature. And he also believed that everything is interrelated and independent. Therefore, we should learn to deal with it moderately and avoid extremes, otherwise we will get the opposite result. The Buddhist admits people's ignorance and weakness. They think that the fate is destined, so people should wait for the opportunity, rather than to change it. We can conclude that Confucianism teaches people how to deal with the relationship in society, while, Buddhism and Taoism emphasize how people correctly keep the interdependence contact with nature.

With the development and changes of American history, almost all the thoughts and customs from various nationalities had merged. After absorbing the essence of world civilization, the unique, diverse and open cultural value system had formed. However, the mainstream culture centered on the diligent and self-disciplined Puritan ethics had always occupied a major position. It was not only a religious concept, but also a philosophical thought and a moral standard, which laid the foundation of American characteristic. Puritans essentially denied the authority of the pope and the communication barrier between humans and God. They believed that they could communicate directly with God through personal comprehension. Their belief broke the shackles of the original ideology of the Roman church, and made them fully understand the importance of the individual, which determined their own belief, gaining freedom and inner independence. In their eyes, work is not only for survival, but also for fulfilling God's mission. Only by working hard can people gain more material wealth. Being lazy and doing nothing will be punished by God. Wanting to cater to God's will, people consider job as an indispensable responsibility and a holy mission. This kind of ideology promoted people to actively create social resources and formed their adventurous and enterprising spirit.

\section{CONCLUSION}

Since the reform and opening up, China has made tremendous achievements in both economy and social development. At the same time, traditional Chinese values are also influenced by foreign cultures, especially the American culture. Some of them have already been integrated with Chinese culture, while others haven't, but they are still accepted by the public. Traditional values are experiencing a huge internal change after frequently contacting with the outside world. People in economically developed regions are more likely to accept new things than those in underdeveloped regions. So it is easier for them to change their traditional minds. Traditional Chinese social system is basically hierarchical. However, the concept of equality and competition has replaced it as the theme of the modern era. There is a certain connection between them, that is, equality is a prerequisite for competition. When companies recruit new employees, they often base on an open, transparent, and fair principle. Although the results may not be entirely satisfactory, they do offer some opportunities for employees, students and other people to ensure that they will have equal rights in promotion and competition.

It is a fact that western cultures, especially American cultures, have permeated in Chinese daily life. We often see a group of young Chinese eating KFC and McDonald as breakfast at Christmas while watching the Hollywood blockbuster in the cinema, so we need to re-evaluate the vitality of American culture. In modern society, people from 
different countries begin to learn each others' excellent culture, in order to eliminate unnecessary misunderstandings in communication, improve the communication efficiency, and finally achieve mutual benefit. We should of course strive to melt the essence of other cultures into our own, but cultural exchange is by no means a single-way cultural transplant, but a process of integration of various excellent cultures. Both Chinese and American cultures have their own strengths. Therefore, while learning the American culture, we should also strive to promote China's excellent traditional culture. Only by doing this, can we reconstruct a new social core value system with Chinese characteristics and ultimately promote the common development of human civilization.

\section{REFERENCES}

[1] Chen G. M. (2007). Foundations of Intercultural Communication. Shanghai: Shanghai Foreign Language Education Press.

[2] Condon, J.C. \& Yousef, F. (1975). An Introduction to Intercultural Communication. Indianapolis, IN: Bobbs-Merrill.

[3] Gu. Z. K. (2007). An Introduction to the Comparison between Chinese and Western Cultures. Peking: Peking University Press.

[4] Hall, E. T. (1996). Beyond Culture. New York: Doubleday and Company.

[5] Hall, E.T. (1973). The Silent Language. New York: Doubleday and Company.

[6] Hofstede, G. (1980). Culture's Consequences. Beverly Hills, CA: sage.

[7] Hofstede, G. (2005). Cultures and Organizations: Software of the Mind. New York: Mc Graw Hil.

[8] Hu.W.Z. (2012). An Introduction to Cross-cultural Communication. Peking: Foreign Language Teaching and Research Press.

[9] Jiang.P. (2013). Cultural Differences from the Perspective of Value Orientation Model. Foreign Communication 2, 34-35.

[10] Kluckhohn, F.K. \& Fred Strodtbeck. (1961). Variations in Value Orientations. Evanston: Row, Peterson.

[11] L.W. Wiseman. (1995). Intercultural Communication Theory. Thousand Oaks: Sage Publication.

[12] Larry A, Samovar and Richard E. Porter (Eds). (2007). Intercultural Communication. Shanghai: Shanghai Foreign Language Education Press.

[13] Linen Davis. (2001). Doing Culture: Cross-Cultural Communication in Action. Beijing: Foreign Language Teaching and Research Press.

[14] Lull, J. Media. (2000). Communication, Culture: A Global Approach. New York: Columbia University Press.

[15] Neulie P, J. W. (2000). Intercultural Communication: A Contextual Approach. New York: Houghton Mimin.

[16] Rokeach. (1973). The Nature of Human Values. New York: Free Press.

[17] Schwartz, S.H. (2003). A Theory of Cultural Value Orientations: Explication and Application. Comparative Sociology 3, 137-182.

[18] Shi.Y. X. (2006). A Brief Introduction of American Culture. Peking: Chinese Compilation and Publishing House.

[19] Stella Ting-Toomey, Leeva. C. Chung. (2011). Understanding Intercultural Communication. Oxford: Oxford University Press.

Jie Yan, male, was born in Shandong Province, China in 1984. He is currently a postgraduate majoring in Cross-cultural Communication, Jiangxi Normal University, Nanchang, China.

Yuying Li (Corresponding Author), female, was born in Jiangxi Province, China in 1964. She is currently a professor in Translation Theory and Practice, Jiangxi Normal University, Nanchang, China. She has published scores of papers in both Chinese and international academic journals. 